\title{
Seasonal changes of the chemical composition of cheese obtained from the milk of indigenous Polish breeds of sheep
}

\author{
A. Kawęcka and E. Sosin-Bzducha ${ }^{1}$ \\ National Research Institute of Animal Production, Department of Animal Genetic Resources Conservation \\ 32-083 Balice, Poland
}

KEY WORDS: sheep, indigenous breeds, pasture, milk, cheese

Received: 3 December 2012

Revised: 29 February 2014

Accepted: 12 June 2014

${ }^{1}$ Corresponding author:

e-mail: ewa.sosin@izoo.krakow.pl

\begin{abstract}
The aim of the study was to investigate the effect of breed Coloured Mountain Sheep (CMS), or Podhale Zackel (PZ) and month of the grazing season (May or August) on the chemical composition of milk and 'oscypek' cheese. The composition of milk was affected by breed and month of the grazing season. Total solids and most other parameters were higher in August than in May. Milk from CMS was characterized by a higher content of crude protein, casein, urea and solids non-fat. Cheese obtained from milk of CMS sheep had about a $6 \%$ lower fat content compared with cheese made from the milk of PZ sheep. The spring-made cheese had a lower content of saturated fatty acids (SFA) and a higher content of monounsaturated fatty acids (MUFA) and polyunsaturated fatty acids. There were statistical differences in $n-6$ and $n-3$ FA levels, but not in the $n-6 / n-3$ ratio between months of the grazing season. Cheese manufactured from the milk of Podhale Zackel sheep had lower SFA and higher MUFA and n-3 FA contents.
\end{abstract}

\section{Introduction}

Pressure to increase global food production and productivity has caused dramatic shrinkage of farm animal genetic resources. The most significant threat to genetic diversity is the marginalization of traditional production systems and the associated breeds (Signorelli et al., 2008). Throughout the world, ewe milk is used mainly for cheesemaking. New cheese production technologies do not always contribute to the quality of cheese, thus there is growing interest and demand for cheeses made according to traditional, old recipes. Polish producers are able to obtain protected status for local and traditional products, known as 'Protected Designation of Origin' (PDO).
PDO designation has guaranteed the originality of products since 2004. Regional products have a legally protected name and are made by manufacturing technologies used only in certain regions of the European Union. Three of the 36 Polish products listed by the EU as protected products are cheeses made from sheep milk: 'bryndza podhalańska', 'oscypek' and 'redykołka'. These cheeses are produced using only the Polish Mountain Sheep breed. The 'oscypek' production technology permits the use of milk from the native breed of Polish Red cows, but in amounts not greater than $40 \%$. The season of cheese production is similar in length to ewe lactation and grazing season. In the Podhale region, the grazing season lasts from May to October. 
Several previous studies have shown seasonal or lactational changes in dairy sheep milk composition and fatty acid profile (Barron et al., 2001; Jaeggi et al., 2005). Many studies have reported the effect of breed on ewe milk performance and composition.

Podhale Zackel (PZ) is a primitive sheep raised in the Podhale region, in the Subcarpathia and the Beskidy Mountains. The Polish Mountain Sheep is an upgraded variety of the primitive Zackel sheep found in the Eastern Carpathians and Balkans. The process of improvement (initially of Zackel, later of Polish Mountain Sheep) were designed to increase the usefulness of mountain sheep and included crossbreeding with other mountain breeds. It has led to changes in their genotype and, consequently, to the displacement of the original primitive genetic makeup of Zackel. For many years, the Podhale Zackel and Coloured Montain Sheep were not treated as a separate breed and were classified as Polish Mountain Sheep. Both studied breeds have been included (Coloured Mountain Sheep since 2000, Podhale Zackel since 2007) in the Sheep Genetic Resources Conservation Programme, which was launched because of a dramatic reduction in sheep numbers caused by production intensification. The breeds are closely linked with the history and tradition of the Podhale region and the local population. Native breeds are extremely well adapted to the climatic conditions and traditional methods of breeding in mountain areas. Moreover, sheep pastured in Podhale feed on very diverse and unique vegetation, which affects the composition and taste of the milk, thus giving unique taste and aroma to the products processed from such milk.

The aim of the study was to investigate the effect of breed (Coloured Mountain Sheep or Podhale Zackel) and month of the grazing season (May or August) on the chemical composition and fatty acid profile of 'oscypek' cheese.

\section{Material and methods}

Herds of 120 Coloured Mountain Sheep (CMS) ewes and 90 Podhale Zackel (PZ) ewes were pastured from May to October (throughout the grazing season) in the Podhale region under the same environmental conditions. The vegetative season in the region is about 150 days long. The pasture contained approximately $60 \%$ grass (perennial ryegrass - Lolium perenne L., fescues - Festuca rubra L., Festuca pratensis L., Kentucky bluegrass - Poa pratensis L.), 20\% legumes (white clover - Trifolium repens L., red clover - Trifolium pretense L., meadow pea - Lathyrus pratensis L., bird wetch - Vicia cracca L.), and 20\% different species of herbaceous plants and weeds ( $H y$ pericum perforatum L., Ranunculus acris L., Achillea millefolium L., Alchemilla vulgaris L., Rumex acetosa L., Lychnis flos-cuculi L., Equisetum arvense).

Milk and 'oscypek' cheese were sampled in May and August. Milk was collected manually from 50 ewes of each breed. No cow's milk was added. To increase acidity, raw milk was kept at room temperature and soured milk was mixed with sweet milk. Rennet was added to the milk to initiate the coagulation process. Traditional tools (e.g., a ferrule) were then used to beat the coagulum and lumps of cheese settled on the bottom of the container. Up to $50 \%$ of the total whey was removed, the mass of cheese was kneaded by hand and balls were formed and placed in the container with whey at $70^{\circ} \mathrm{C}$. This activity was repeated three times. The balls were shaped and pierced with a skewer, then pressed along the skewer until it took on the shape of a double cone. A ring was placed around the cheese at its widest point. After that the ring was removed and the cheese was squeezed and smoothed by hand and placed in cold water to preserve its shape. The next step was soaking in brine for up to $24 \mathrm{~h}$ and drying for about 24 h. Four-day smoking was carried out using cold smoke. The production of one lot of cheese with smoking took about 6 days.

To assess the quality of the cheese from each breed, 5 cheeses from one consignment of cheese produced at the beginning (May) and at the end of the grazing season (August) were randomly selected. Samples of cheese were stored at $-18^{\circ} \mathrm{C}$ until further analysis.

\section{Chemical analysis}

Analyses were performed at the Central Laboratory of the National Research Institute of Animal Production. Milk samples were analysed for fat, protein, lactose, total solids (TS) and urea with a Milkoscan FT 120 (Foss Electric).

The basic chemical composition of cheese was determined using standard procedures (AOAC, 1997).

The fatty acid profile of cheese samples was determined by gas chromatography (VARIAN $3400 \mathrm{CX}$ ) using helium as the carrier gas, and an Rtx 2330, $105 \mathrm{~m}$ column. The injector temperature was $200^{\circ} \mathrm{C}$ and detector temperature $240^{\circ} \mathrm{C}$. The samples were methylated according to Folch et al. (1957) using BF3/methanol.

\section{Calculations and statistical analysis}

The atherogenicity index was calculated according to Ulbricht and Southgate (1991) as follows: $(\mathrm{C} 12: 0+4 \times \mathrm{C} 14: 0+\mathrm{C} 16: 0) /($ MUFA + PUFA $)$. 
The results were analysed by two-way analysis of variance using the ANOVA procedure of STATISTICA ver. 9 (StatSoft, 2010) with genotype and month of grazing season as the main factors. Significant differences between the means were determined by Duncan's multiple range test and differences were considered significant if $P \leq 0.05$. The genotype by month of season interactions were analysed for significance.

\section{Results}

\section{Milk and cheese composition}

The composition of milk was affected by breed and month of the grazing season (Table 1). Total solids and most other parameters were higher in August than in May. The casein-to-crude protein ratio was lower $(P \leq 0.01)$ at the end of the grazing season $(81.73 \%$ vs $79.77 \%)$. Milk from Coloured Mountain Sheep was characterized by a higher $(P \leq 0.01)$ content of crude protein, casein, urea and solids non-fat (SNF). There were no significant differences $(P>0.05)$ between the breeds in total solids. Breed $\times$ month of grazing season interactions were found for crude protein, casein, SNF and freezing point depression (FPD).

The average chemical composition of the 'oscypek' cheese for each breed and month of the grazing season is shown in Table. 2. Cheese made at the end of the grazing season (August) had a higher mineral content. Cheese from milk of Podhale Zackel sheep was characterized by a higher moisture content $(P \leq 0.05)$ and lower percentage of crude protein $(P \leq 0.01 ; 25.47 \%$ vs $31.85 \%)$. Cheese obtained
Table 2. The effect of breed and month of grazing season on basic chemical composition of cheese

\begin{tabular}{|c|c|c|c|c|c|c|c|}
\hline \multicolumn{2}{|l|}{ Indices } & $\begin{array}{l}\text { Total } \\
\text { solids, \% }\end{array}$ & $\begin{array}{l}\text { Moisture, } \\
\% \%\end{array}$ & $\begin{array}{l}\text { Crude } \\
\text { protein, } \\
\%\end{array}$ & $\begin{array}{l}\text { Crude } \\
\text { fat, } \%\end{array}$ & $\begin{array}{l}\text { FDM, } \\
\%\end{array}$ & $\begin{array}{l}\text { Ash, } \\
\%\end{array}$ \\
\hline \multicolumn{8}{|l|}{ Breed $^{1}$} \\
\hline \multicolumn{2}{|l|}{ CMS } & 60.5 & 39.5 & 31.85 & 21.3 & 35.2 & 5.81 \\
\hline \multicolumn{2}{|l|}{ PZ } & 59.27 & 40.73 & 25.47 & 27.07 & 45.6 & 5.89 \\
\hline \multicolumn{8}{|l|}{ Month } \\
\hline \multicolumn{2}{|l|}{ May } & 59.52 & 40.48 & 28.39 & 24.28 & 40.9 & 5.81 \\
\hline \multicolumn{2}{|l|}{ August } & 60.24 & 39.76 & 28.94 & 24.09 & 39.9 & 5.89 \\
\hline \multicolumn{8}{|l|}{ Breed } \\
\hline \multirow[t]{2}{*}{ CMS } & $M$ & $61.09^{B}$ & $38.91^{\mathrm{B}}$ & $31.06^{\mathrm{B}}$ & $23.19^{A}$ & $38.0^{A}$ & $5.2^{\mathrm{B}}$ \\
\hline & $A$ & $59.9^{\mathrm{B}}$ & $40.1^{\mathrm{Bb}}$ & $32.64^{c}$ & $19.41^{\mathrm{B}}$ & $32.4^{\mathrm{B}}$ & $6.41^{\mathrm{cb}}$ \\
\hline \multirow[t]{2}{*}{ PZ } & M & $57.95^{\mathrm{A}}$ & $42.04^{\mathrm{Aa}}$ & $25.71^{\mathrm{A}}$ & $25.36^{c}$ & $43.8^{\mathrm{C}}$ & $6.02^{\mathrm{Aa}}$ \\
\hline & A & $60.58^{B}$ & $38.14^{\mathrm{B}}$ & $25.23^{A}$ & $28.77^{\mathrm{D}}$ & $47.5^{\mathrm{D}}$ & $5.75^{\mathrm{A}}$ \\
\hline \multicolumn{2}{|l|}{ Breed } & * & * & $* *$ & $* *$ & $* *$ & ns \\
\hline \multicolumn{2}{|l|}{$\begin{array}{l}M S \\
B \times M\end{array}$} & ns & ns & ns & ns & * & $* *$ \\
\hline \multicolumn{2}{|c|}{$B \times M$} & $* *$ & $* *$ & $* *$ & $* *$ & ** & $* *$ \\
\hline \multicolumn{2}{|c|}{ SEM $(n=20)$} & 0.36 & 0.36 & 0.76 & 0.79 & 1.33 & 0.12 \\
\hline
\end{tabular}

FDM - fat in dry matter; ns - non significant; a,b,A,B,C,D means with different superscipts within a row are significantly different at $P \leq 0.01$ or $P \leq 0.05$, respectively; ${ }^{*} P \leq 0.05 ;{ }^{*} P \leq 0.01 ;{ }^{1}$ breed - see Table 1 ; $\mathrm{M}$ - May; A - August

from the milk of Coloured Mountain Sheep had about $6 \%$ less fat than cheese made from Podhale Zackel milk. There were interactions between breed and month of the grazing season for all chemical composition parameters.

\section{Cheese fatty acids}

Breed and month of the grazing season had an effect on the fatty acid profile of cheese (Table 3). The cheese made from spring milk contained less $(P \leq 0.01)$ saturated fatty acids (SFA), about $4 \%$, and more $(P \leq 0.01)$ monounsaturated fatty acids (MUFA), about $3.5 \%$, and polyunsaturated fatty acids (PUFA), about $0.6 \%$. There were statistical

Table 1. The ffect of breed and month of grazing season on chemical composition of ewe milk

\begin{tabular}{|c|c|c|c|c|c|c|c|c|c|c|c|}
\hline \multicolumn{2}{|l|}{ Indices } & $\begin{array}{l}\text { Total } \\
\text { solids, \% }\end{array}$ & Lactose, \% & $\begin{array}{l}\text { Crude } \\
\text { protein, \% }\end{array}$ & $\begin{array}{l}\text { Urea, } \\
\mathrm{mg} \cdot \mathrm{dl}^{-1}\end{array}$ & Casein, \% & $\begin{array}{l}\text { Casein: crude } \\
\text { protein ratio }\end{array}$ & $\begin{array}{l}\text { Casein: } \\
\text { fat ratio }\end{array}$ & $\begin{array}{l}\text { Crude } \\
\text { fat, } \%\end{array}$ & SNF, $\%$ & $\mathrm{FPD},{ }^{\circ} \mathrm{C}$ \\
\hline \multicolumn{12}{|l|}{ Breed } \\
\hline \multicolumn{2}{|l|}{ CMS } & 19.66 & 4.59 & 6.86 & 44.2 & 5.54 & 80.9 & 0.77 & 7.27 & 11.88 & 0.67 \\
\hline \multicolumn{2}{|l|}{ PZ } & 19.52 & 4.61 & 6.43 & 48.9 & 5.18 & 80.6 & 0.74 & 7.46 & 11.4 & 0.68 \\
\hline \multicolumn{12}{|l|}{ Month } \\
\hline \multicolumn{2}{|c|}{ May (M) } & 18.84 & 4.75 & 6.07 & 42.0 & 4.96 & 81.73 & 0.73 & 6.88 & 11.27 & 0.66 \\
\hline \multicolumn{2}{|c|}{ August (A) } & 20.34 & 4.44 & 7.24 & 50.9 & 5.78 & 79.77 & 0.74 & 7.85 & 12.03 & 0.7 \\
\hline \multicolumn{12}{|c|}{ Breed Month } \\
\hline \multirow[t]{2}{*}{ CMS } & $\mathrm{M}$ & 18.72 & 4.72 & $6.13^{A}$ & 39.3 & $5.01^{A}$ & 81.86 & $0.74^{\mathrm{Aa}}$ & 6.79 & $11.33^{\mathrm{Aa}}$ & $0.64^{A}$ \\
\hline & $A$ & 20.6 & 4.45 & $7.6^{\mathrm{C}}$ & 49.1 & $6.07^{\mathrm{B}}$ & 79.9 & $0.79^{c}$ & 7.74 & $12.44^{\mathrm{B}}$ & $0.7^{\mathrm{B}}$ \\
\hline & M & 18.96 & 4.79 & $6.0^{\mathrm{A}}$ & 45.0 & $4.9^{\mathrm{A}}$ & 81.5 & $0.71^{\mathrm{ABb}}$ & 6.98 & $11.21^{\mathrm{A}}$ & $0.67^{\mathrm{Ca}}$ \\
\hline & $A$ & 20.08 & 4.43 & $6.85^{\mathrm{B}}$ & 52.7 & $5.46^{\mathrm{C}}$ & 79.6 & $0.69^{\mathrm{Bb}}$ & 7.95 & $11.6^{\mathrm{cb}}$ & $0.69^{\mathrm{Bb}}$ \\
\hline \multicolumn{2}{|l|}{ Breed } & ns & ns & ** & ** & ** & ns & $* *$ & ns & $* *$ & ns \\
\hline \multicolumn{2}{|c|}{ MS } & ** & $* *$ & ** & ** & ** & $* *$ & ns & ** & ** & ** \\
\hline \multicolumn{2}{|c|}{$B \times M S$} & ns & ns & $* *$ & ns & $* *$ & ns & $* *$ & ns & $* *$ & ** \\
\hline \multicolumn{2}{|c|}{$\operatorname{SEM}(n=191)$} & 0.12 & 0.02 & 0.07 & 0.008 & 0.05 & 0.13 & 0.09 & 0.08 & 0.05 & 0.003 \\
\hline
\end{tabular}

ns - non significant; ${ }^{*} P \leq 0.05 ;{ }^{*} P \leq 0.01 ; C M S$ - Coloured Mountain Sheep; PZ - Podhale Zackel; SNF - solids non-fat; FPD - freezing point depression 
Table 3. The effect of breed and month of grazing season on major fatty acids in oscypek cheese, $\%$ of total fatty acids

\begin{tabular}{|c|c|c|c|c|c|c|c|c|}
\hline \multirow{2}{*}{ Fatty acids } & \multicolumn{2}{|l|}{ Breed $^{1}$} & \multicolumn{2}{|l|}{ Month } & \multirow{2}{*}{ SEM } & \multirow{2}{*}{ B } & \multirow{2}{*}{ MS } & \multirow{2}{*}{$\mathrm{B} \times \mathrm{MS}$} \\
\hline & CMS & $\mathrm{PZ}$ & May & August & & & & \\
\hline C8:0 & 2.34 & 2.22 & 2.08 & 2.48 & 0.13 & ns & ns & ns \\
\hline C10:0 & 8.6 & 8.16 & 8.23 & 8.52 & 0.21 & ns & ns & ns \\
\hline C12:0 & 5.43 & 5.18 & 5.24 & 5.37 & 0.1 & ns & ns & ns \\
\hline C14:0 & 12.64 & 11.92 & 11.59 & 12.98 & 0.2 & $* *$ & $* *$ & $*$ \\
\hline C16:0 & 26.38 & 25.31 & 24.57 & 27.12 & 0.35 & ** & $* *$ & $* *$ \\
\hline C16:1 & 1.39 & 1.32 & 1.34 & 1.37 & 0.01 & ** & ns & ns \\
\hline C18:0 & 9.74 & 10.57 & 10.57 & 9.74 & 0.15 & $* *$ & ns & ns \\
\hline C18:1 & 25.76 & 27.22 & 28.40 & 24.59 & 0.54 & * & $* *$ & * \\
\hline C18:2, n-6 & 1.90 & 2.06 & 1.93 & 2.03 & 0.04 & * & ns & ns \\
\hline C18:3, n-3 & 1.77 & 1.94 & 1.80 & 1.92 & 0.03 & $* *$ & * & ns \\
\hline $\mathrm{C} 20: 0$ & 0.23 & 0.24 & 0.25 & 0.21 & 0.01 & ns & * & ns \\
\hline $\mathrm{C} 20: 4, \mathrm{n}-6$ & 0.09 & 0.15 & 0.13 & 0.11 & 0.01 & $* *$ & ns & ns \\
\hline $\mathrm{C} 22: 0$ & 0.17 & 0.17 & 0.2 & 0.14 & 0.01 & ns & ns & ns \\
\hline $\mathrm{C} 22: 1$ & 0.00 & 0.01 & 0.00 & 0.01 & 0.003 & ns & ns & ns \\
\hline C20:5; EPA, n-3 & 0.09 & 0.13 & 0.12 & 0.1 & 0.007 & $* *$ & ns & ns \\
\hline C22:6; DHA, n-3 & 0.07 & 0.08 & 0.06 & 0.09 & 0.005 & ns & * & $* *$ \\
\hline CLA c-9, t-11 & 2.55 & 2.78 & 3.03 & 2.30 & 0.1 & $* *$ & $* *$ & $* *$ \\
\hline CLA t-10, c-12 & 0.76 & 0.03 & 0.42 & 0.38 & 0.16 & $*$ & ns & ns \\
\hline CLA c-9, c-11 & 0.04 & 0.18 & 0.14 & 0.08 & 0.02 & * & ns & ns \\
\hline CLA t-9, t-11 & 0.16 & 0.21 & 0.21 & 0.16 & 0.01 & ns & * & ns \\
\hline CLA & 3.51 & 3.2 & 3.8 & 2.92 & 0.16 & ns & * & ns \\
\hline SFA & 65.41 & 63.89 & 62.42 & 66.87 & 0.59 & $* *$ & $* *$ & * \\
\hline UFA & 34.59 & 36.11 & 37.58 & 33.13 & 0.59 & $* *$ & ** & * \\
\hline MUFA & 27.15 & 28.56 & 29.74 & 25.97 & 0.53 & * & ** & * \\
\hline PUFA & 7.44 & 7.55 & 7.84 & 7.16 & 0.12 & ns & ** & ns \\
\hline$n-6$ & 2.01 & 2.21 & 2.09 & 2.11 & 0.04 & $* *$ & ns & ns \\
\hline$n-3$ & 1.94 & 2.15 & 1.98 & 2.11 & 0.04 & $* *$ & * & ns \\
\hline$n-6 / n-3$ & 1.02 & 1.03 & 1.04 & 1.02 & 0.01 & $* *$ & * & ns \\
\hline $\mathrm{Al}^{2}$ & 2.39 & 2.19 & 2.03 & 2.55 & 0.07 & $* *$ & $* *$ & * \\
\hline
\end{tabular}

ns - non significant; ${ }^{*} P \leq 0.05 ;{ }^{* *} P \leq 0.01 ;{ }^{1}$ breed - see Table $1 ;{ }^{2}$ atherogenity index $(\mathrm{C} 12: 0+4 \times \mathrm{C} 14: 0+\mathrm{C} 16: 0) /(\mathrm{MUFA}+\mathrm{PUFA})$;

CLA - sum of isomers; B - breed; MS - month; PZ - Podhale Zackel

differences $(P \leq 0.05)$ between $n-6$ and n-3 contents, but not in the n-6/n-3 ratio between month of the grazing season, and some differences $(P \leq 0.05)$ occurred in the level of docosahexaenoic acid (n-3, DHA, C22:6). There were breed $\times$ month interactions for $\mathrm{C} 14: 0 ; \mathrm{C} 16: 0 ; \mathrm{C} 18: 1 ; \mathrm{C} 22: 6$; CLA cis-9, trans-11, saturated and monounsaturated FA. Cheese made from the milk of Coloured Mountain Sheep had a higher content of SFA due to the high content of $\mathrm{C} 14: 0$ and $\mathrm{C} 16: 0$ fatty acids $(P \leq 0.01 ; 12.65$ vs 11.84 and 26.43 vs 25.13$)$. The level of MUFA was lower in cheese from CMS than in that from PZ sheep, probably because of the lower oleic acid level (C18:1). There were no differences $(P \geq 0.05)$ in PUFA between the breeds, but 'oscypek' made from the milk of Podhale Zackel sheep had a higher content $(P \leq 0.05)$ of $n-3$ acids: $\alpha$-linolenic (LNA; C18:3) and eicosapentaenoic (EPA, C20:5), but not docosahexaenoic (DHA, C22:6).

The percentage of $n-6$ acids was also higher in cheese from that breed, mainly due to linoleic (LA, C18:2) and arachidonic (n-6; C20:4) acids.

\section{Discussion}

Milk composition. Breed-related changes in milk composition were observed previously (Kawęcka and Paraponiak, 2005; Pakulski and Pakulska, 2009; Radzik-Rant et al., 2011). RadzikRant et al. (2011), who compared the milk of Polish Merino ewes with that of Polish Mountain Sheep fed a winter diet, reported significant differences $(P \leq 0.05)$ in fat, with a higher content found for Polish Merino ewes. Some changes were found in other milk parameters (protein, lactose and total solids), but the differences were not statistically significant. The fat content of milk from both breeds (Coloured Mountain Sheep and Podhale Zackel) used in the present study is similar to the results reported for Polish Mountain Sheep fed a winter diet (Radzik-Rant et al., 2011) or pastured in May (Konieczny, 2009). Bonczar (1998) reported that the casein number of ewe milk suitable for cheese production is $75 \%-85 \%$. In the present study, the casein number of milk from CMS and PZ 
sheep (80.9\% vs $80.6 \%$ ), and from May and August $(81.7 \%$ vs $79.8 \%)$ fell within this range.

The higher contents of total solids, crude fat and protein in August are typical of late-lactation ovine milk. In different breeds of sheep the contents of these components increase as lactation proceeds: e.g., in Massese (Casoli et al., 1989), Churra (Fuertes et al., 1998), Latxa (Barron et al., 2001). The results of Konieczny (2009), who investigated changes at different stages of lactation of Polish Mountain Sheep, are in line with previous studies. The fat content of milk from Polish Mountain Sheep differed between May and August (7.21\% vs 9.76\%). The results of the present study are similar. There were significant differences in milk fat content between May and August $(P \leq 0.01)$, but the difference between means was not as high $(6.88 \%$ vs $7.85 \%)$ as in the study of Konieczny (2009), in which the milk fat content differed by almost $3 \%$.

Over the grazing season, the milk of Podhale Zackel changed to a lesser extent than milk from Coloured Mountain Sheep. The milk of the latter breed obtained in August had higher contents of protein $(7.6 \%$ vs $6.85 \%)$, casein $(6.07 \%$ vs $5.46 \%)$ and SNF (12.44\% vs $11.6 \%)$ compared with milk from Podhale Zackel $(P \leq 0.01)$.

Pellegrini et al. (1997) reported that in ovine milk, the fat concentration increases at a higher rate than casein in late lactation, which is why the caseinto-fat ratio in the milk decreases during lactation. Similar changes were observed through lactation in milk of Podhale Zackel, but not Coloured Mountain Sheep in which the casein-to-fat ratio was increasing probably because of the same rate of changes in casein and fat.

Chemical composition of cheese. The chemical composition of cheese is affected by many factors, including milk composition, amount and genetic variants of casein, milk quality, somatic cell count (SCC) in milk, milk pasteurization, coagulant type, vat design, curd firmness at cutting, and manufacturing parameters (Lawrence, 1993).

The moisture of cheeses was higher than in a previous study $(40.1 \%$ vs $34.0 \%)$ (Przygoda et al., 2009). The higher moisture content of 'oscypek' cheese in our study was probably why the contents of crude protein and fat $(28.7 \%$ and $24.2 \%$, respectively) were lower compared with the findings of Przygoda et al. (2009) (29.6\% and 27.1\%). Pakulski et al. (2006) reported a significantly lower fat content $(10.5 \%)$ in a similar type of cheese obtained from the milk of Kołuda sheep. In the present study, the breeds were characterized by higher fat contents.
At the beginning of the grazing season, 'oscypek' obtained from milk of CMS had a higher content of total solids (61.09\% vs $57.95 \%)$ and lower of moisture (38.91\% vs $42.04 \%$ ) than 'oscypek' made from PZ milk. In August the total solids in CMS cheeses decreased to $59.9 \%$ and to $60.58 \%$ in PZ cheeses due to the corresponding changes in crude fat and fat in DM. The differences in the composition of cheese between breeds in different months of the grazing season could be the result of changes in casein and in the casein-to-fat ratio. Jaeggi et al. (2005) reported changes in hard cheese composition attributed to the casein-to-fat ratio in milk between cheeses obtained in different months of the grazing season. Cheese made from milk at the beginning of the grazing season (February) had higher fat and lower protein contents than cheese from May or August, which was attributed to the lower casein-tofat ratio in milk. In our study, the casein-to-fat ratio differed within the breed and months of the grazing season. Milk from CMS had a higher casein-to-fat ratio at the end of the season $(0.79)$ than at the beginning (0.74) and the obtained cheese was characterized by lower fat (19.41\% vs $23.19 \%)$ and higher protein $(32.64 \%$ vs $31.06 \%)$ contents. The opposite was observed in Podhale Zackel milk and cheese: a lower casein-to-fat ratio in milk (0.69 vs 0.71$)$, higher fat $(28.77 \%$ vs $25.36 \%)$ and slightly lower protein $(25.23 \%$ vs $25.71 \%)$ contents at the end of the season.

According to Raynal and Remeuf (1998), a higher casein content in ewe milk favours micelle-micelle interactions, leading to more rapid aggregation of the particles during coagulation. The content of milk components (mainly fat and protein) and also other factors such as casein micelle diameter and mineral equilibrium, which also change during lactation, can affect curd firmness (Remeuf et al., 1991; Pellegrini et al., 1997). Bencini (2002) found that increasing the protein content $(4.9 \%-6.84 \%, \mathrm{pH} 6.71)$ of ewe milk decreased its rennet clotting time (RCT) and increased its curd consistency, but the same author reported that the relationship between the concentration of milk protein and curd firmness is curvilinear and curd does not increase when the milk protein exceeds $\approx 6.3 \%$. The same observation was made for a high fat content of milk - curd consistency increases when the fat concentration in milk is less than $6.85 \%$. Moreover, Jaramillo et al. (2008) suggested that curd firmness can be negatively affected when milk protein and fat contents are high.

The results obtained in our study support these findings. The high protein content in CMS milk from August (7.6\%) could have negatively 
affected curd firmness and, as a result, cheese composition. Lawrence (1993) reported that when the curd is soft during manufacturing, the network can be easily shattered and there is loss of fat. In our experiment, the cheese fat content of CMS was much lower in August than in May (19.41\% vs 23.19\%). The August milk of PZ sheep contained less protein $(6.85 \%)$, which could have affected curd firmness and cheese composition to a lesser extent.

Fatty acid profile of cheese. Many studies have shown that the fatty acid profile of cheese was very similar to that of the milk (Nudda et al., 2005; Sinclair et al., 2007). The diversity of milk fatty acids (FA) arises from the effects of ruminal biohydrogenation of dietary unsaturated FA and de novo $\mathrm{FA}$ synthesis in the mammary gland (Gómez-Cortés et al., 2009). The differences can be partially explained by differences in fodder seasonal changes and fodder intake, and by variations in the activity of acetyl-CoA carboxylase and the other enzymes involved in de novo PUFA lipogenesis in the mammary cells (Chilliard et al., 2003). Since volatile flavour compounds in cheese are formed during ripening, particularly from lipid degradation (McSweeney, 2004), differences in the fat content or fatty acid profile can lead to characteristic physicochemical properties of cheeses from each breed. According to Engels et al. (1997), the volatile organic compounds (VOCs) in cheese, such as methyl ketones and secondary alcohols, arise from the lipolysis of myristic (C14:0) and palmitic acids (C16:0). In our study, there were differences in the contents of these FA between breeds and the month of grazing season, which may suggest that the organoleptic properties of cheeses could differ as well. Significant differences in the proportions of palmitic (C16:0), myristic (C14:0) and capric acid (C10:0) in milk fat between different breeds of sheep were reported earlier by Signorelli et al. (2008) (Sarda vs Altamurana vs Gentile di Puglia) and Mierlita et al. (2011) (Spanca vs Turcana).

Differences in retention of milk fat fatty acids in cheese depending on the production technology were observed earlier (Reguła et al., 2005; Pakulski and Pakulska, 2009). Some studies reported an increase in the CLA content of cheese during processing, which is attributed to the auto-oxidation of linoleic acid under anaerobic conditions during the heating step (Garcia-Lopez et al., 1994).

Pasteurization is the main thermal process used in the production of many milk products, including 'oscypek' cheese. The temperature applied during its production in our study was $70^{\circ} \mathrm{C}$. Reguła et al. (2005) conclude that pasteurization at $72^{\circ} \mathrm{C}$ for $30 \mathrm{~s}$ during production should be limited due to the large changes in the amount of total free FA, which in that study increased by about $41 \%$. Shantha et al. (1992) reported no changes in CLA formation and content when milk was processed at temperatures below $80^{\circ} \mathrm{C}$. The CLA content and its isomers may depend on many factors, such as stage of lactation, parity and breed, but the most important factor is diet. Generally, the milk of grazing animals has a higher concentration of CLA compared with that of animals fed dry diets (Dhiman et al., 1999). In the current study, the level of CLA and the cis-9, trans-11 isomer in cheese was quite high in both months (about $3 \mathrm{~g}$ and above $2 \mathrm{~g}$ per $100 \mathrm{~g}$ of FA, respectively), possibly because of the forage. In other studies, the cis-9, trans-11 isomer was lower: $1 \mathrm{~g} \cdot 100 \mathrm{~g}^{-1}$ of total fatty acids in a study by Sinclair et al. (2007), where the basal forage was hay, and $1.7 \mathrm{~g} \cdot 100 \mathrm{~g}^{-1}$ of total fatty acids in an experiment by Nudda et al. (2005), where the basal forage was grass. According to Cabiddu et al. (2006), certain pastures may contain species with a higher content of C18:2 n- 6 or C18:3 n-3 or with significant quantities of secondary plant compounds that can affect the level of CLA due to inhibition of rumen biohydrogenation or increase in $\Delta-9$ desaturase activity in mammary tissue. Lock et al. (2003), who estimated the product/substrate ratio (e.g., C14:1, cis-9/C14:0) in cow's milk fat to study seasonal variation of $\Delta-9$ desaturase, suggested that a molecule contained in the grass could stimulate the activity of the enzyme. No significant differences $(P \geq 0.05)$ between the breeds were observed in CLA, although some differences $(P \leq 0.05)$ occurred for most isomers, especially cis-9, trans- 11 . Tsiplakou et al. (2006) and Signorelli et al. (2008) did not find any significant effect of the breed on CLA in milk from different breeds of sheep maintained under the same feeding regimes, but this was due to the large variation in milk fat CLA content among individuals. When comparing the fatty-acid profile of milk from indigenous Romanian sheep breeds (Spanca and Turcana), Mierlita et al. (2011) found differences for the majority ofFA. The Turcana breed was characterized by lower SFA, and higher MUFA and PUFA contents. A higher concentration of cis-9, trans-11 CLA was the result of higher $\Delta-9$ desaturase activity and more intense conversion of vaccenic acid (trans-11 C18:1).

The highest level of CLA isomer cis-9, trans-11 was observed in May in 'oscypek' cheese from the PZ breed. Chouinard et al. (1998) reported 
that CLA decreased with increasing growth stage of forage or maturity. Nudda et al. (2005) reported a decline in the cis-9, trans-11 CLA content from March (2.20) to June $\left(1.14 \mathrm{mg} \cdot 100 \mathrm{mg}^{-1}\right.$ of FA methyl esters). In our study we observed a lower CLA content, especially of the cis-9, trans-11 isomer, in cheese obtained from August compared with May milk, which confirms these findings. According to Nudda et al. (2005), fresh grass at the beginning of the season might include something that enhances the growth of particular bacteria in the rumen that are responsible for producing CLA or blocks the final reduction of vaccenic acid to C18:0. Saturated fatty acids are known to contribute to coronary heart disease, while some unsaturated fatty acids have a protective effect against the risk of cardiovascular disease. In our study, cheeses obtained from CMS ewes had higher SFA and lower UFA and MUFA contents, but there was no influence of breed on PUFA.

Fat with a low atherogenicity index (AI) value and appropriate n-6/n-3 FA ratio (2:1; ISSFAL, 2004 ) is assumed to be beneficial to human health. Addis et al. (2005) found an effect of forage species on the atherogenicity index. Cheese obtained from milk collected in May was characterized by a lower atherogenicity index due to changes in the profile of FA, especially MUFA and PUFA. Cheese from PZ sheep contained those fatty acids that are considered beneficial for human health. Claps et al. (2011), when comparing the autochthonous Italian breed Altamurana with the Sarda breed, observed health-promoting properties of cheese from the indigenous breed. In our study, cheese obtained from both indigenous breeds was characterized by a low $\mathrm{AI}$ and n-6/n-3 fatty acid ratio.

\section{Conclusions}

The composition of milk was affected by breed and month of the grazing season. Milk from Coloured Mountain Sheep was characterized by a higher content of crude protein, casein, urea and solids non-fat than Podhale Zackel. Most parameters were higher in August than in May. There were no differences in cheese composition between the months of the grazing season, but both the breed and month of the grazing season had an effect on cheese chemical composition and fatty acid profile. The differences in the fatty acid profile of products observed in response to breed and month of the grazing season may form the basis for producing different flavoured niche cheeses. The results obtained in the present study indicate that local breeds of sheep have a high potential for sustainable use.

\section{References}

Addis M., Cabiddu A., Pinna G., Decandia M., Piredda G., Pirisi A., Molle G., 2005. Milk and cheese fatty acid composition in sheep fed Mediterranean forages with reference to conjugated linoleic acid cis-9,trans-11. J. Dairy Sci. 88, 3443-3454

AOAC, 1997. Association of Official Analytical Chemists, Official Methods of Analysis. $15^{\text {th }}$ Edition. Washington. DC

Barron L.J. R., de Labastida E.F., Perea A.I. et al., 2001. Seasonal changes in the composition of bulk raw ewe's milk used for Idiazabal cheese manufacture. Int. Dairy J. 11, 771-778

Bencini R., 2002. Factors affecting the clothing properties of Steep milk. J. Sci. Food Agr. 82, 705-719

Bonczar G., 1998. Studies on the quality and suitability for processing of sheep's milk (in Polish). Prz. Mlecz. 11, 397-400

Cabiddu A., Addis M., Pinna G., Spada S., Fiori M., Sitzia M., Pirisi A., Piredda G., Molle G., 2006. The inclusion of a daisy plant (Chrysanthemum coronarium) in dairy sheep diet. 1. Effect on milk and cheese fatty acid composition with particular reference to C18:2 cis-9,trans-11. Livest. Sci. 101, 57-67

Casoli C., Duranti E., Morbidini L., Panella F., Vizioli V., 1989. Quantitive and compositional variations of Massese sheep by parity and stage of lactation. Small Ruminant Res. 2, 47-62

Chilliard Y., Ferlay A., Rouel J., Lamberet G., 2003. A review of nutritional and physiological factors affecting goat milk synthesis and lipolysis. J. Dairy Sci. 86, 1751-1770

Chouinard P.Y., Corneau L., Kelly M.L., Griinari J.M., Bauman D.E., 1998. Effect of dietary manipulation on milk conjugated linoleic acid concentration. J. Dairy 81, Suppl.1, 233 (Abstr.)

Claps S., Sepe L., Caputo A.R., Di Napoli M.A., Morone G., Annicchiarico G., Fedele V., 2011. The cheese quality as tool to safeguard autochthonous sheep breeds and mountain environment. In: Proceedings of $10^{\text {th }}$ International Meeting on Mountain Cheese. Dronero (Italy)

Dhiman T.R., Anand G.R., Satter L.D., Pariza M.W., 1999. Conjugated linoleic acid content of milk from cows fed different diets. J. Dairy Sci. 82, 2146-2156

Engels W., Dekker R., de Jong C., Neeter R., Visser S., 1997. A comparative study to volatile compounds in the water soluble fraction of various types of ripened cheese. Int. Dairy J. 7 , 255-267

Folch J., Lees M., Sloane-Stanley G.H., 1957. A simple method for the isolation and purification of total lipids from animal tissues. J. Biol. Chem. 226, 497-509

Fuertes J.A., Gonzalo C., Carriedo J.A., Primitivo F.S., 1998. Parameters of test day milk yield and milk components for dairy ewes. J. Dairy Sci., 81, 1300-1307

Garcia-Lopez S., Echeverria E., Tsui I., Balch B., 1994. Changes in the content of conjugated linoleic acid (CLA) in processed cheese during processing. Feed Res. Int. 27, 61-64

Gómez-Cortés P., Bach A., Luna P., Juárez M., de la Fuente M.A., 2009. Effects of extruded linseed supplementation on n-3 fatty acids and conjugated linoleic acid in milk and cheese from ewes. J. Dairy Sci. 92, 4122-4134

ISSFAL, 2004. The $6^{\text {th }}$ Congress of the International Society for the Study of Fatty Acids and Lipids. Brighton (UK)

Jaeggi J.J., Wendorff W.L., Romero J., Berger Y.M., Johnson M.E., 2005. Impact of seasonal changes in ovine milk composition and yield of hard-pressed cheese. J. Dairy Sci. 88, 1358-1363

Jaramillo D.P., Zamora A., Guamis B., Rodríguez M., Trujillo A.J., 2008. Cheesemaking aptitude of two Spanish dairy ewe breeds: Changes during lactation and relationship between physico-chemical and technological properties. Small Ruminant Res. 78, 48-55 
Kawęcka A., Paraponiak P., 2005. Characteristics of milk performance of alpine breeds of sheep and their crosses with Polish Mountain Sheep. Ann. Anim. Sci. 2(2), 287-296

Konieczny M., 2009. Effect of stage of lactation on chemical composition and physicochemical parameters of milk from Polish Mountain Sheep in an organic production system (in Polish). Rocz. Nauk. Zoot. 36(1), 25-30

Lawrence R.C., 1993. Processing conditions. In: D.B. Emmons (Editor). Factors Affecting the Yield of Cheese. International Dairy Federation. Brussels, pp. 64-78

Lock A.L., Garnsworthy P.C., 2003. Seasonal variation in milk conjugated linoleic acid and $\Delta^{9}$-desaturase activity in dairy cows. Livest. Prod. Sci. 79, 47-59

McSweeney P.L.H., Biochemistry of cheese ripening. Int. J. Dairy Technol. 57, 127-144

Mierlita D., Daraban St., Lup F., 2011. Effects of breed on milk fatty acid profile in dairy ewes, with particular reference to cis-9, trans-11 conjugated linoleic acid. S. Afr. J. Anim. Sci. 41, 223-231

Nudda A., McGuire M.A., Battacone G., Pulina G., 2005. Seasonal variation in conjugated linoleic acid and vaccenic acid in milk fat of sheep and its transfer to cheese and ricotta. J. Dairy Sci. $88,1311-1319$

Pakulski T., Borys B., Pakulska E., 2006. The level of some bioactive components in the fat fraction of sheep's milk and cheese. Arch. Tierzucht, Special Issue. 49, 317-324

Pakulski T., Pakulska E., 2009. Composition of the lipid fraction of cheeses produced from milk of Coloured Merino Sheep according to production technology (in Polish). Rocz. Nauk. PTZ 2, 167-176

Pellegrini O., Remeuf F., Rivemalle M., Barillet F., 1997. Reneting properties of milk from individual ewes: Influence of genetic and non-genetic variables, and relationship with physicochemical characteristics. J. Dairy Res. 64, 355-366
Przygoda B., Kunachowicz H., Paczkowska M., Daniewski W., Sekuła W., 2009. The nutritional value of selected traditional food products (in Polish). Bromat. Chem. Toksykol. XLII. 3, 231-235

Radzik-Rant A., Rozbicka-Wieczorek A., Czauderna M., Rant W., Kuczyńska B., 2011. The chemical composition and fatty acid profile in milk of Polish Mountain Sheep and Polish Merino. Ann. Warsaw Univ. of Life Sci.-SGGW, Anim. Sci. 49, 163-172

Raynal K., Remeuf F., 1998. The effect of heating on physicochemical and renneting properties of milk: a comparision between caprine, ovine and bovine milk. Int. Dairy J. 8, 695-706

Reguła A., Bonczar G., Pustkowiak H., 2005. The effect of heat treatment on the free fatty acids in ewe's milk. Biotechnol. Anim. Husbandry 21 (5-6-2), 237-240

Remeuf F., Cossin V., Dervin C., Lenoir J., Tomassone R., 1991. Relations entre les caractéristiques physic-chimiques des laits et leur aptitude fromagère. Lait 397-421

Shantha N. C., Decker E.A., Ustunol Z., 1992. Conjugated linoleic acid concentrations in processing cheese. J. Amer. Oil Chem. Soc. $69,425-428$

Signorelli F., Contarini G., Annicchiarico G., Napolitano F., Orrù L., Catillo G., Haenlein G.F.W., Moioli B., 2008. Breed differences in sheep milk fatty acid profiles: Opportunities for sustainable use of animal genetic resources. Small Ruminant Res. 78, 24-31

Sinclair L.A., Lock A.L., Early R., Bauman D.E., 2007. Effect of trans-10, cis-12 conjugated linoleic acid on ovine milk fat synthesis and cheese properties. J. Dairy Sci. 90, 3326-3335

StatSoft. Inc., 2010. STATISTICA, version 9

Tsiplakou E., Mountzouris K.C., Zervas G., 2006. The effect of breed, stage of lactation and parity on sheep milk fat CLA content under the same feeding practices. Livest. Sci. 105, 162-167

Ulbricht T.L.V., Southgate D.A.T., 1991. Coronary heart disease: seven dietary factors. Lancet 19 (338), 985-992 